\title{
In Situ Formed Phosphoric Acid/Phosphosilicate Nanoclusters in the Exceptional Enhancement of Durability of Polybenzimidazole Membrane Fuel Cells at Elevated High Temperatures
}

Zhang, Jin; Aili, David; Bradley, John; Kuang, Haohua; Pan, Chao; De Marco, Roland; Li, Qingfeng; Jiang, San Ping

Published in:

Journal of the Electrochemical Society

Link to article, DOI:

10.1149/2.1051714jes

Publication date:

2017

Document Version

Peer reviewed version

Link back to DTU Orbit

Citation (APA):

Zhang, J., Aili, D., Bradley, J., Kuang, H., Pan, C., De Marco, R., Li, Q., \& Jiang, S. P. (2017). In Situ Formed Phosphoric Acid/Phosphosilicate Nanoclusters in the Exceptional Enhancement of Durability of

Polybenzimidazole Membrane Fuel Cells at Elevated High Temperatures. Journal of the Electrochemical Society, 164(14), F1615-F1625. https://doi.org/10.1149/2.1051714jes

\section{General rights}

Copyright and moral rights for the publications made accessible in the public portal are retained by the authors and/or other copyright owners and it is a condition of accessing publications that users recognise and abide by the legal requirements associated with these rights.

- Users may download and print one copy of any publication from the public portal for the purpose of private study or research.

- You may not further distribute the material or use it for any profit-making activity or commercial gain

- You may freely distribute the URL identifying the publication in the public portal 


\title{
In situ formed phosphoric acid/phosphosilicate nanoclusters in the exceptional enhancement of durability of polybenzimidazole membrane fuel cells at elevated high temperatures
}

Jin Zhang, ${ }^{\text {a, }}$ David Aili, ${ }^{\mathrm{c}}$ John Bradley, ${ }^{\mathrm{d}}$ Haohua Kuang, ${ }^{\mathrm{b}}$ Chao Pan, ${ }^{\mathrm{c}}$ Roland De Marco,, d, e Qingfeng Li, ${ }^{\mathrm{c}}$ San Ping Jiang*,b,d

${ }^{a}$ Beijing Key Laboratory for Bio-inspired Energy Materials and Devices, School of Space and Environment, Beihang University, Beijing 100191, P.R.China

${ }^{b}$ Fuels and Energy Technology Institute \& Department of Chemical Engineering, Curtin University, Perth, WA6102, Australia

${ }^{c}$ Department of Energy Conversion and Storage, Technical University of Denmark, Lyngby 2800, Denmark.

${ }^{d}$ Faculty of Science, Health, Education and Engineering, University of Sunshine Coast, Maroochydore DC, QLD 4558, Australia

${ }^{e}$ School of Chemistry and Molecular Biosciences, The University of Queensland, Brisbane, Queensland 4072, Australia

* Corresponding author. Email address: s.jiang@curtin.edu.au; Tel: + 6192669804

\begin{abstract}
Most recently, we developed a phosphotungstic acid impregnated mesoporous silica (PWA-meso-silica) and phosphoric acid doped polybenzimidazole (PA/PBI) composite membrane for use in high temperature fuel cells and achieved exceptional durability under a constant current load of $200 \mathrm{~mA} \mathrm{~cm}^{-2}$ at $200{ }^{\circ} \mathrm{C}$ for over $2700 \mathrm{~h}$. In this work, the fundamental role of PWA-meso-silica in enhancing the stability of the PA/PBI membrane has been investigated. The microstructure, the PA uptake, swelling ratio, mechanical property and conductivity of PA/PBI/PWA-meso-silica composite membranes depend on the loading of
\end{abstract}


PWA-meso-silica. The results indicate that the optimum limit of PWA-meso-silica loading in the PA/PBI membranes is $15 \mathrm{wt} \%$. Detaled analysis indicates that the mesoporous structure of the PWA-meso-silica framework disintegrates, forming phosphosilicate phases within the PBI polymeric matrix during fuel cell operation at $200{ }^{\circ} \mathrm{C}$. The in situ formed phosphosilicates can immobilize a significant amount of PA, forming PA/phosphosilicate nanoclusters that possess high proton conductivity (e.g., $7.2 \times 10^{-2} \mathrm{~S} \mathrm{~cm}^{-1}$ at $250{ }^{\circ} \mathrm{C}$ ) and stability and substantially inhibits acid leaching out of the membrane. The substantially reduced acid leaching also alleviates the excess acid in the catalyst layer, reducing the detrimental effect of excess acid on the agglomeration of Pt catalysts especially in the cathode catalyst layer. These phenomena are responsible for the exceptional stability in proton conductivity of the PA/PBI/PWA-meso-silica composite membranes, as well as the significantly reduced agglomeration of Pt nanoparticles in the anode and cathode catalyst layers of PA/PBI/PWA-meso-silica composite membrane fuel cells.

Keywords: high temperature polymer electrolyte membrane fuel cells; mesoporous silica; phosphotungstic acid impregnation; PA/phosphosilicates nanocluster; durability.

\section{Introduction}

Increasing the operational temperature of polymer electrolyte membrane fuel cells (PEMFCs) above $100{ }^{\circ} \mathrm{C}$ increases the kinetics of electrode reactions, simplifies cooling and heat management systems and substantially increases the tolerance and resistance of Pt-based electrocatalysts against $\mathrm{CO}$ poisoning [1-3]. A state-of-the-art high temperature polymer electrolyte membrane (PEM) comprises phosphoric acid doped polybenzimidazole (PA/PBI) membranes with high chemical and thermal stability as well as high PA doping levels[4-6]. To date, exceptional fuel cell durability of up to $18000 \mathrm{~h}$ has been achieved using PA/PBI membrane-based fuel cells at a constant current load of $200 \mathrm{~mA} \mathrm{~cm}^{-2}$ in $\mathrm{H}_{2} /$ air at temperatures 
up to $160^{\circ} \mathrm{C}[7,8]$. At operational temperatures of $150-160{ }^{\circ} \mathrm{C}$, the PA/PBI PEMFCs exhibited low degradation rates of $5-10 \mu \mathrm{V} \mathrm{h}^{-1}[7,9-11]$ and were very stable[12].

Further improvements in the operational temperature of PEMFCs to a higher temperature regime of $180-200{ }^{\circ} \mathrm{C}$ would allow for enhancements in fuel impurity tolerance of $\mathrm{CO}$ to 30000 ppm at $200{ }^{\circ} \mathrm{C}[13]$, and substantially improves the electrocatalyst kinetics and efficiency of waste heat recovery in PEMFCs [14]. This high CO tolerance in combination with high operational temperature also enables the thermal integration of fuel cells with a methanol reformer, providing a high temperature PEM fuel cell power systems together with high efficiency, on-board fuel supply and low cost. However, performance degradation increases substantially at elevated high temperatures with PA/PBI membranes based PEMFCs. For example, it has been reported that a degradation rate as high as $19 \mu \mathrm{V} \mathrm{h}^{-1}$ was obtained with a fuel cell operated at $200 \mathrm{~mA} \mathrm{~cm}^{-2}$ and $180{ }^{\circ} \mathrm{C}$ in $\mathrm{H}_{2} /$ air for $\sim 6000 \mathrm{~h} \mathrm{[15]} \mathrm{and} 60 \mu \mathrm{V} \mathrm{h}^{-1}$ within $800 \mathrm{~h}$ at $190{ }^{\circ} \mathrm{C}$ and $200 \mathrm{~mA} \mathrm{~cm}{ }^{-2}$ in $\mathrm{H}_{2} /$ air[16]. Similarly, Zhang et al. reported a stable performance of the PA/PBI PEMFC stack at $160{ }^{\circ} \mathrm{C}$ in $\mathrm{H}_{2} /$ air at a costant voltage of $0.65 \mathrm{~V}$, but the performance deteriorated by $7.5 \%$ at $180{ }^{\circ} \mathrm{C}$ and $33.3 \%$ at $200{ }^{\circ} \mathrm{C}$ within a timeframe of $100 \mathrm{~h}[17]$. This significant degradation rate in PA/PBI membrnace-based PEMFCs at temperatures above $160^{\circ} \mathrm{C}$ is most ascribed to acid leaching or redistribution[18]. For instance, Yu et al. observed a phosphoric acid loss rate of $7 \mathrm{ng} \mathrm{cm}^{-2} \mathrm{~h}^{-1}$ at $160{ }^{\circ} \mathrm{C}$ on the cathode side and at $190{ }^{\circ} \mathrm{C}$, this acid loss rate substantially increased to $110 \mathrm{ng} \mathrm{cm}^{-2} \mathrm{~h}^{-1}$ [16]. Eberhardt et al. reported a $90 \%$ loss of phosphoric acid in a fuel cell operated at $190{ }^{\circ} \mathrm{C}$ under a high gas flow rate[19].

Various strategies have been developed to stabilize the PA in the membrane in order to improve proton conductivity, stability and cell performance under a high temperature operating regime[20, 21]. Composite PBI membranes with inorganic solid oxide additives such as $\mathrm{SiO}_{2}[22], \mathrm{HfO}_{2}$ [23] or ionic liquid impregnated zeolite[24] have demonstrated improvements 
in the proton conductivity at elevated temperatures. Nevertheless, the long-term stability of inorganic-organic composite membranes is seldom studied. Most recently, we developed high temperature PEMs based on phosphotungstic acid impregnated mesoporous silica (PWAmeso-silica) and PA/PBI inorganic-organic composites[25]. The results demonstrated that the PWA-meso-silica additive significantly increased the durability of PA/PBI membrane fuel cells, achieving a low degradation rate of $27 \mu \mathrm{V} \mathrm{h}^{-1}$ at $200{ }^{\circ} \mathrm{C}$ under a constant current load of $200 \mathrm{~mA} \mathrm{~cm}{ }^{-2}$ for $2700 \mathrm{~h} \mathrm{[25].} \mathrm{This} \mathrm{fuel} \mathrm{cell} \mathrm{performance} \mathrm{degradation} \mathrm{rate} \mathrm{is} \mathrm{comparable} \mathrm{with}$ the value of fuel cells based on the commercial PA/PBI membrane at $160{ }^{\circ} \mathrm{C}$ under constant current load of $200 \mathrm{~mA} \mathrm{~cm}^{-2}$ for $780 \mathrm{~h}[26]$. This demonstrable improvement in stability of the PA/PBI based inorganic-organic composite membrane cells represents a significant milestone in the development of high temperature PEMFCs. However, the exact reasons for this exceptional improvement in durability is not fully understood.

In this study, we have carried out detailed studies of the microstructural changes, proton conductivity and performance stability of PA/PBI/PWA-meso-silica composite membrane fuel cells. The results of this study elucidate the unique role of PWA-meso-silica in stabilizing PA in the composite membrane together with inhibition of the agglomeration of $\mathrm{Pt} / \mathrm{C}$ electrocatalysts during operation of the PEMFC at elevated high temperatures.

\section{Experimental}

\subsection{Materials}

Dequalinium chloride hydrate (DCH), tetraethylorthosilicate (TEOS), triblock copolymer Pluronic surfactant P123 $\left(\mathrm{EO}_{20}-\mathrm{PO}_{70}-\mathrm{EO}_{20}\right)$ and phosphotungstic acid were purchased from Sigma-Aldrich, Australia. Ethanol (EtOH), hydrochloric acid $(\mathrm{HCl}, 32 \%)$, phosphoric acid (85\%), methanol and ethanol were obtained from Rowe Scientific Company, Australia. Pt/C (60 wt\%) was purchased from Johnson Matthey, UK. Poly[2,2'-(m-phenylene)-5,5'- 
bisbenzimiazole] ( $\mathrm{mPBI}$, $6.1 \mathrm{wt} \%$ in dimethylacetamide) was sourced from Danish Power Systems, Denmark (inherent viscosity $0.95 \mathrm{dL} \mathrm{g}^{-1}$ at $30{ }^{\circ} \mathrm{C}$ and $500 \mathrm{mg} \mathrm{dL}^{-1}$ in $96 \mathrm{wt} \% \mathrm{H}_{2} \mathrm{SO}_{4}$ ).

\subsection{Preparation of composite membrane and membrane-electrode-assembly (MEA)}

Meso-silica was fabricated using a conventional method. Pluronic P123 surfactant and $\mathrm{HCl}$ at specified ratios were dissolved in deionized water/ethanol solution, followed by the addition of TEOS. The mixture was stirred vigorously at $40{ }^{\circ} \mathrm{C}$ for $24 \mathrm{~h}$ and subsequently kept in an autoclave at $100{ }^{\circ} \mathrm{C}$ for $24 \mathrm{~h}$. The collected powder was calcined at $650{ }^{\circ} \mathrm{C}$ for $6 \mathrm{~h}$ in air. The PWA-meso-silica with a loading of $40 \%$ PWA was obtained by impregnating PWA in mesosilica using a vacuum-assisted impregnation method[27]. The modification of PWA-mesosilica was conducted by dispersing the powder in a DCH solution $\left(0.02 \mathrm{~g} \mathrm{~mL}^{-1}\right.$ in methanol) followed by vigorous stirring for $4 \mathrm{~h}$. The mixture was subsequently dried at $160{ }^{\circ} \mathrm{C}$ for $20 \mathrm{~h}$ yielding an off-white powder. The modified PWA-meso-silica powder was mixed with the $m$ PBI solution. The supsension was mixed in ultrasonic bath for $20 \mathrm{~h}$ and cast onto a heated Petri dish starting at room temperature to $120{ }^{\circ} \mathrm{C}$ using a heating rate of $7^{\circ} \mathrm{C} \mathrm{h}^{-1}$. The resultant composite membrane was treated with methanol at $50{ }^{\circ} \mathrm{C}$ in order to wash out the $\mathrm{DCH}$ modifier, followed by drying at $180{ }^{\circ} \mathrm{C}$ for $3 \mathrm{~h}$. The loading of PWA-meso-silica in the PBI matrix was $5,10,15,20,30$ and $40 \mathrm{wt} \%$, while the thickness of the dry composite membrane was approximately $70 \mu \mathrm{m}$. Pristine PBI membrane (i.e., PWA-meso-silica loading was zero) with similar thickness was prepared by casting the PBI solution onto a heated petri dish starting at room temperature to $120^{\circ} \mathrm{C}$ using a heating rate of $7{ }^{\circ} \mathrm{C} \mathrm{h}^{-1}$ and was employed as a control group. The membranes were imbibed with $85 \mathrm{wt} \% \mathrm{H}_{3} \mathrm{PO}_{4}$ at room temperature for at least 2 weeks.

Phosphosilicate/PA particles were fabricated by mixing the meso-silica powder with phosphoric acid, followed by heating at $150{ }^{\circ} \mathrm{C}$ for $24 \mathrm{~h}$ and $250{ }^{\circ} \mathrm{C}$ for $24 \mathrm{~h}$. One portion of the formed phosphosilicate/PA particles was washed by acetone to completely remove the 
phosphoric acid, and the resultant white powder was marked as pristine or pure phosphosilicate. Acetone treated phosphosilicate was mixed with phosphoric acid, forming mixed phosphosilicate and PA, denoted as phosphosilicate+PA. Phosphosilicate/PA particles formed without removal of PA by acetone washing were denoted as in situ formed phosphosilicate/PA or simply phosphosilicate/PA.

Gas diffusion electrodes were supplied by Danish Power Systems. The Pt/C catalyst was applied on a nonwoven carbon substrate (Freudenberg H2315 C2) using a spray technique and $m \mathrm{PBI}$ as binder. The loading of platinum and $m \mathrm{PBI}$ was 1.6 and $0.1 \mathrm{mg} \mathrm{cm}^{-2}$ for cathode and 0.1 and $0.1 \mathrm{mg} \mathrm{cm}^{-2}$ for anode, respectively. Membrane-electrode assemblies (MEA) with an active area of $4 \mathrm{~cm}^{2}$ were fabricated by sandwiching the phosphoric acid doped membrane between two pieces of gas diffusion electrode followed by hot-pressing at $4.9 \mathrm{MPa}$ and $180{ }^{\circ} \mathrm{C}$ for 10 minutes.

\subsection{Characterization}

Cross-section and surface of membranes were examined by scanning electron microscopy (SEM) using a Carl Zeiss EVO MA10 and transmission electron microscopy (TEM) using a Philips Tecnai F20 FEG-STEM at an accelerating voltage of $100 \mathrm{kV}$. The membrane crosssections for SEM imaging were prepared by sandwiching the membrane samples between two pieces of non-woven carbon cloth followed by ion-milling using a Hitachi E-3500, and sputter coated with carbon. For transmission electron microscopy (TEM) the membrane samples were resin-mounted and sectioned using a Leica Ultracut UC6 ultramicrotome equipped with a diamond knife. Stress-strain curves were recorded using a Testometric Micro 350 under ambient conditions with a crosshead speed of $10.00 \mathrm{~mm} \mathrm{~min}^{-1}$. The specimens were die-cut to a dog-bone shape with a gauge length and width of 28 and $2 \mathrm{~mm}$, respectively. The $\mathrm{Pt}$ nanoparticles were examined using a JEOL 2100 TEM at an accelerating voltage of $120 \mathrm{kV}$. The Pt nanoparticles were dispersed in ethanol and subsequently placed on a copper grid. The 
SEM imaging and electron dispersive X-ray spectroscopy (EDS) analysis of the Pt particles was carried out using JEOL $7100 \mathrm{~F}$. The microstructure of the samples was investigated by synchrotron small angle X-ray scattering (SAXS) with a camera length of $650 \mathrm{~mm}$ with a 3 $\mathrm{GeV}$ electron storage ring, Melbourne, Australia. The membranes were covered on the holes of a flat plate sample holder.

The MEAs were assembled in a single fuel cell hardware (active area $4.0 \mathrm{~cm}^{-2}$ ) for the fuel cell performance measurements using an in-house built fuel cell test station. Hydrogen and air were supplied to the anode and cathode, respectively. Life time analysis of cells was undertaken in a continuous mode at $200 \mathrm{~mA} \mathrm{~cm}{ }^{-2}$ and $200{ }^{\circ} \mathrm{C}$ using a flow rate of $45 \mathrm{SCCM}$ for $\mathrm{H}_{2}$ in anode and 176 SCCM for air in cathode. The impedance, as recorded on the fuel cells operated in paralled, was measured every $8 \mathrm{~h}$. Electrochemical impedance spectroscopy (EIS) data were recorded periodically at open circuit voltage $(\mathrm{OCV}), 0.8 \mathrm{~V}, 0.7 \mathrm{~V}$ and $0.6 \mathrm{~V}$ in the frequency range $100 \mathrm{kHz}$ to $0.1 \mathrm{~Hz}$ using a VersaStat 4 potentiostat from Princeton Applied Research. Phosphosilicate composite powders were pressed into pellets with the diameter of $25 \mathrm{~mm}$ for the proton conductivity test by EIS at a frequency range of $100 \mathrm{kHz}$ to $1 \mathrm{~Hz}$.

\section{Results and discussion}

\subsection{Microstructure of the PBI/PWA-meso-silica composite membrane}

Fig. 1 shows the SEM images of the pristine PBI and PBI/PWA-meso-silica composite membranes. Pristine PBI membrane is characterized by a dense and smooth cross-section (Fig.1A) and surface (Fig.1B), indicating that the pristine PBI membrane is homogeneous. On the other hand, in the case of PBI/PWA-meso-silica composite membranes, the microstructure depends strongly on the loading of PWA-meso-silica filler. Homogeneous membranes were achieved when the loading of PWA-meso-silica in the PBI membrane was lower than $15 \mathrm{wt} \%$ Fig.1C-F). The cross-section of the composite membrane with PWA-meso-silica loading lower than $15 \mathrm{wt} \%$ is generally dense though some isolated pores were observed (Fig.1E). Isolated 
pores were also observed on the surface of the composite membrane (Fig. 1F). The formation of isolated pores is likely due to the presence of the inorganic filler and interface between the inorganic meso-silica particles and polymeric PBI matrix. The presence of two phases in the PBI/PWA-meso-silica composite membrane is also indicated by the backscattering electron image as shown in Fig. 1F. The phase in light colour corresponds to the PWA-meso-silica particles and the particle size is $1-2 \mu \mathrm{m}$ (see the inset of Fig. 1F), while the dark phase is the PBI matrix. However, with loadings of PWA-meso-silica higher than $15 \mathrm{wt} \%$, anisotropic structures and pore formation were observed (Fig.1G and $\mathrm{H}$ ), likely due to the agglomeration of the inorganic component at high concentrations. The results indicate that the composite membrane with $15 \mathrm{wt} \%$ PWA-meso-silica loading would meet the microstructure and morphology properties as required in PEM fuel cells.

To observe the dispersion of PWA-meso-silica in the PBI matrix, a film was cut from a PBI composite membrane with $15 \mathrm{wt} \%$ PWA-meso-silica by a microtome. Fig. 2 shows TEM images of the PBI/PWA-meso-silica composite. From the TEM backscattered electron image, two phases were clearly observed (Fig. 2A). Mesoporous structure in [001] and [100] directions was observed in the light region of the membrane (Fig.2B), which corresponds to the structure of mesoporous silica. EDS analysis of the mesoporous region identifies the elements of Si and W (Fig. 2C), confirming the presence of PWA-meso-silica in the composite membranes.

\subsection{Phosphoric acid uptake and mechanical properties of the composite membranes}

PBI membranes were equilibrated in $85 \%$ PA at room temperature for two weeks to ensure that PA doping level reached an equilibrium in the composite membranes. PA uptake of pristine PBI membrane was $341 \mathrm{wt} \%$, corresponding to about 10.5 PA per polymer repeat unit. In the case of PBI/PWA-meso-silica membranes, the PA doping level decreased with the increase in the loading of PWA-meso-silica fillers. In the case of PBI/PWA-meso-silica membrane with $15 \mathrm{wt} \%$ filler, the PA uptake was $242 \mathrm{wt} \%$, corresponding to $7.5 \mathrm{PA}$ per 
polymer repeat unit. The swelling volume of the composite membrane also decreased with the increase in the filler loadings, varied in the range of $167 \%$ to $100 \%$. For PBI/PWA-mesosilica membrane with $15 \mathrm{wt} \%$ filler, the swelling ratio was $137 \%$, which is $43.3 \%$ lower than that of the pristine PBI membrane. This indicates the positive influence of the PWA-mesosilica filler on the swelling volume of the composite membrane. Table 1 lists the PA doping level and swelling ratio of pristine PBI and PBI/PWA-meso-silica composite membranes.

Mechanical properties of a membrane are a critical aspect of a membrane's suitability for use in fuel cells. Mechanical properties of the PBI composite membranes before and after PAdoping were tested and the results are shown in Fig.3. Before PA doping, the pristine PBI membrane shows outstanding mechanical properties and dimensional stability (Fig. 3A and B). The elastic modulus of the pristine PBI membrane was $3384 \pm 409 \mathrm{MPa}$ and its elongation was 10.4 $\pm 4.7 \%$. However, with the addition of PWA-meso-silica in the PBI membrane, the mechanical strength of the composite membrane generally decreased. For example, for composite mebrane with $15 \mathrm{wt} \%$ PWA-meso-silica, the mechanical strength slightly decreases to $1992 \pm 282 \mathrm{MPa}$ and the elongation reduces to $4.4 \pm 0.6 \%$ (Fig.3A and B). This may be due to the presence of isolated pores in the composite membrane. After PA doping, the mechanical strength of the pristine PBI membrane is substantially diminished (Fig.3C and D) and the elastic modulus is decreased from $3384 \pm 409 \mathrm{MPa}$ to $52.3 \pm 0.6 \mathrm{MPa}$ (Table 1). However, the elongation of the PA/PBI membrane is increased from $10.4 \pm 4.7 \%$ to $58.3 \pm 22.1 \%$. This is probably due to the swelling of the membrane and the reduced intermolecular forces among the polymer macromolecules. The elastic modulus of the PA/PBI/PWA-meso-silica composite was in the range of $25.0-54.3 \mathrm{MPa}$, comparable to $52.3 \mathrm{MPa}$ of the pristine PA/PBI membrane (Fig.3D). The elongation of the composite mmebranes varied between $88.3 \%$ to $126.9 \%$, also comparable to the pristine PA/PBI membrane (Fig.3C). The close mechanical and elastic properties between $\mathrm{PA} / \mathrm{PBI} / \mathrm{PWA}$-meso-silica and pristine $\mathrm{PA} / \mathrm{PBI}$ membranes indicate that 
addition of PWA-meso-silica does not significantly vary the mechanical and elastic properties of PA/PBI membranes, demonstrating the excellent fabrication and processing capability potential of the PA/PBI/PWA-meso-silica inorganic-organic composite membranes, a significant advantage as compared to inorganic PEMs[2, 27].

As shown early[25], in the PWA-meso-silica loading range of $0-20 \mathrm{wt} \%$, the effect of filler on the conductivity of the PA/PBI/PWA-meso-silica composite membranes is relatively small and with further increase of the filler loading, the proton conductivity of the composite membrane decreases. This may be due to the deteriated microstructure as shown in Fig.1. Taking into account the microstructure, the PA uptake, swelling ratio, mechanical and conductivity properties, the optimum limit of PWA-meso-silica loading in the PA/PBI membranes has been determined to be $15 \mathrm{wt} \%$. Thus in following sections, only the electrochemical performance of the composite membrane cells with $15 \mathrm{wt} \%$ PWA-meso-silica fillers is characterized and discussed.

\subsection{Cell performance and proton conductivity of PA/PBI/PWA-meso-silica membranes}

Fig. 4 shows the performance and stability of PA/PBI and PA/PBI/PWA-meso-silica composite membrane fuel cells at $200{ }^{\circ} \mathrm{C}$ and a constant current load of $200 \mathrm{~mA} \mathrm{~cm}{ }^{-2}$. The loading of PWA-meso-silica fillers in the composite membrane was $15 \mathrm{wt} \%$. The PA/PBI membrane fuel cell is not stable and degrades significanty upon polarization at $200 \mathrm{~mA} \mathrm{~cm} \mathrm{c}^{-2}$ (Fig. 4A). The initial cell voltage was $0.70 \mathrm{~V}$ and fell to $0.52 \mathrm{~V}$ after polarization at $200 \mathrm{~mA}$ $\mathrm{cm}^{-2}$ for $1450 \mathrm{~h}$ with a degradation rate of $129 \mu \mathrm{V} \mathrm{h}^{-1}$. This was followed by a rapid decline in cell voltage, acquiring a cell potential of close to zero after polarization for $2400 \mathrm{~h}$ representing a degradation rate of $705 \mu \mathrm{V} \mathrm{h}^{-1}$. These values are similar to results reported by Li et al.[28] for the durability of a PA/PBI membrane fuel cell limited to $1000 \mathrm{~h}$ of operation under similar conditions to the present study. By contrast, the PA/PBI/PWA-meso-silica composite membrane fuel cell showed a very stable performance. The initial cell voltage was $0.68 \mathrm{~V}$ and 
reached $0.53 \mathrm{~V}$ after polarization at $0.2 \mathrm{~A} \mathrm{~cm}^{-2}$ and $200{ }^{\circ} \mathrm{C}$ for $2700 \mathrm{~h}$. Except for an initial reduction in performance during the first $500 \mathrm{~h}$, the cell voltage was relatively stable during the next $2200 \mathrm{~h}$ and the cell voltage degradation rate was $27 \mu \mathrm{V} \mathrm{h}^{-1}$, which is significantly better than the degradation rate of $60 \mu \mathrm{V} \mathrm{h}^{-1}$ that has been reported previously on a commercial PA/PBI membrane fuel cell operated at a lower temperature of $190{ }^{\circ} \mathrm{C}[16]$.

The initial proton conductivity of the PA/PBI membrane during operation at $200{ }^{\circ} \mathrm{C}$ was 28 $\mathrm{mS} \mathrm{cm}$, slightly lower than $34 \mathrm{mS} \mathrm{cm}^{-1}$ for the PA/PBI/PWA-meso-silica composite membrane under identical conditions (Fig. 4B). This is generally in line with the reported conductivity of $68 \mathrm{mS} \mathrm{cm}^{-1}$ for PBI membranes with PA doping level of 5.6 at $200{ }^{\circ} \mathrm{C}$ and $5 \%$ RH[29]. During fuel cell operation, the proton conductivity of the PA/PBI membrane decreased rapidly to $3.5 \mathrm{mS} \mathrm{cm}^{-1}$ after polarization for $2340 \mathrm{~h}$, a reduction of $\sim 90 \%$ of the initial conductivity of the membrane. This rapid decrease in proton conductivity is clearly due to membrane degradation and/or acid leaching from the membrane[21, 23]. By contrast, except for the initial decrease, the proton conductivity of the PA/PBI/PWA-meso-silica composite is very stable and oscillates in the range of 21 to $23 \mathrm{mS} \mathrm{cm}^{-1}$ during a test period of $2700 \mathrm{~h}$. These results demonstrate that the presence of PWA-meso-silica inorganic particles effectively inhibits the deterioration in proton conductivity of the PA/PBI membrane, probably through the suppression of acid leaching from the membrane. This inhibition effect is also confirmed by the stable open circuit voltage of the PA/PBI/PWA-meso-silica composite membrane fuel cell during $2600 \mathrm{~h}$ operation, as shown in Fig. 4C. On the other hand, the OCV of the PA/PBI fuel cell sharply dropped from $0.89 \mathrm{~V}$ to $0.73 \mathrm{~V}$ after operation for $2340 \mathrm{~h}$.

The power output of the PA/PBI and PA/PBI/PWA-meso-silica membrane fuel cells was evaluated during the stability tests at $200{ }^{\circ} \mathrm{C}$ and the results are presented in Fig. 5. The initial peak power density of the PA/PBI membrane fuel cell was $407 \mathrm{~mW} \mathrm{~cm}^{-2}$, which is comparable with reported results. For example, Jin et al studied the performance of PA/PBI with and 
without addition of $\mathrm{Sn}_{0.95} \mathrm{Al}_{0.5} \mathrm{P}_{2} \mathrm{O}_{7}$ and reported peak power density of $369 \mathrm{~mW} \mathrm{~cm}{ }^{-2}$ in $\mathrm{H}_{2} / \mathrm{O}_{2}$ for PA/PBI membrane cells and $440 \mathrm{~mW} \mathrm{~cm}^{-2}$ in $\mathrm{H}_{2} /$ air for $\mathrm{PA} / \mathrm{PBI} / \mathrm{Sn}_{0.95} \mathrm{Al}_{0.5} \mathrm{P}_{2} \mathrm{O}_{7}$ composite membrane cell measured at $200{ }^{\circ} \mathrm{C}$ with overall Pt catalyst loading of $8 \mathrm{mg} \mathrm{cm}^{-2}$ [30]. The initial peak power density of the PA/PBI/PWA-meso-silica membrane fuel cell was $386 \mathrm{~mW}$ $\mathrm{cm}^{-2}$, very close to that of the PA/PBI membrane fuel cell (Fig.5A). However, the power output of the PA/PBI membrane fuel cell diminished rapidly after polarization for $1750 \mathrm{~h}$ (Fig.5B), with the peak power density of $82.3 \mathrm{~mW} \mathrm{~cm}^{-2}$ representing a much lower value than the 224.8 $\mathrm{mW} \mathrm{cm}{ }^{-2}$ value obtained with a PA/PBI/PWA-meso-silica composite membrane fuel cell. After polarization for $2400 \mathrm{~h}$ (Fig.5C), the peak power density of PA/PBI membrane cell was 48.4 $\mathrm{mW} \mathrm{cm}{ }^{-2}$, only $11.9 \%$ of the initial power output of this fuel cell. By contrast, the peak power density of the PA/PBI/PWA-meso-silica composite membrane fuel cell was $198 \mathrm{~mW} \mathrm{~cm} \mathrm{~cm}^{-2}$ under the same test conditions, substantially higher than that of PA/PBI membrane cell. Table 2 lists the peak power density of PA/PBI and PA/PBI/PWA-meso-silica composite membrane fuel cells as a function of polarization time at $200{ }^{\circ} \mathrm{C}$.

Polarization resistance and ohmic resistance of pristine and composite membrane fuel cells were determined by EIS during the stability testing at $200{ }^{\circ} \mathrm{C}$ (see Fig.6). It illustrates that the ohmic resistance of the PA/PBI membrane cell increases from $0.36 \Omega \mathrm{cm}^{2}$ to $1.78 \Omega \mathrm{cm}^{2}$, an increase of $391 \%$ in just $320 \mathrm{~h}$, while the increase in the ohmic resistance of the composite increases is much smaller (Fig. 6A). After $2700 \mathrm{~h}$, the ohmic resistance of the composite membrane cell only increased from $0.16 \Omega \mathrm{cm}^{2}$ to $0.33 \Omega \mathrm{cm}^{2}$ which is much lower than 1.78 $\Omega \mathrm{cm}^{2}$ measured on PA/PBI membrane cell after only $320 \mathrm{~h}$ (Fig.6B). Most interesting, the polarization resistance of the PA/PBI membrane cell increased from 0.52 to $0.71 \Omega \mathrm{cm}^{2}$ within $320 \mathrm{~h}$, while it increased from 0.32 to $0.48 \Omega \mathrm{cm}^{2}$ during $2700 \mathrm{~h}$ for the composite membrane cell. The increase in the polarization resistance for the PA/PBI/PWA-meso-silica composite membrane cells is also much smaller as compared to PA/PBI membrane cells. This suggests 
that the addition of the inorganic meso-silica filler also contributes to a stabilization of the $\mathrm{Pt} / \mathrm{C}$ catalyst electrode. The results demonstrate that performance degradation in PA/PBI membrane fuel cells is primarily related to increases in the ohmic resistance of the cell and changes in the electrode polarization resistance to a less degree.

\subsection{Microstructure of the composite membrane and Pt electrocatalyst after stability test}

Fig. 7 shows SEM images of the PA/PBI/PWA-meso-silica composite membrane after 2700 $\mathrm{h}$ of fuel cell testing. The surface of the composite membrane is generally smooth with, in some instances, isolated areas of aggregated particles in the size range of $20-50 \mathrm{~nm}$ (Fig.7A and B). However, SAXS analysis could not detect the mesoporous silica particulate phases in the PBI matrix. After operation of the fuel cell, the unique SAXS peaks of meso-silica corresponding to the planes of (100), (110) and (200) had vanished (Fig.7C), indicating the disintegration of the mesoporous structure of silica phase during the fuel cell operation at $200{ }^{\circ} \mathrm{C}$. Pristine PBI shows a broad peak in the range of $15-30^{\circ}$, indicating the amorphous structure of the polymer membrane[31]. In the case of PA/PBI membrane cells, two new peaks around $20^{\circ}$ and $27^{\circ}$ were detected after operation at $200{ }^{\circ} \mathrm{C}$ for $2400 \mathrm{~h}$ (Fig.7D), corresponding to the $\mathrm{P}_{2} \mathrm{O}_{7}$ and $\mathrm{P}_{2} \mathrm{O}_{5}$, respectively. This is likely due to the decomposition of phosphoric acid in the PA/PBI membrane. Very different from PA/PBI membrane cells, in addition to XRD peaks of $\mathrm{P}_{2} \mathrm{O}_{7}$ and $\mathrm{P}_{2} \mathrm{O}_{5}$, two new peaks around $22.9^{\circ}$ and $25.0^{\circ}$ were detected for the PA/PBI/PWA-mesosilica membrane after the fuel cell test and have been identified with $\mathrm{Si}_{5} \mathrm{O}\left(\mathrm{PO}_{4}\right)_{6}$ phase (JCPDF card 04-011-0823)[32]. This indicates the in situ formation of phosphosilicate phase during the PA/PBI/PWA-meso-silica membrane fuel cell operation at $200{ }^{\circ} \mathrm{C}$. The results imply that the disintegration of the mesoporous silica phase is due to the reaction between mesoporous silica and PA and the formation of phosphosilicate during operation of the fuel cell.

Matsuda et al.[33] studied the synthesis of phosphosilicate phase by phosphoric acid and tetraethoxysilane and revealed the detection of Si-O-P bonds and the formation of 
phosphosilicate phase, $\mathrm{Si}_{5} \mathrm{O}\left(\mathrm{PO}_{4}\right)_{6}$. Thus, during the operation of PA/PBI/PWA-meso-silica membrane cell at $200{ }^{\circ} \mathrm{C}$, phosphoric acid molecules would react with mesoporous silica, leading to the disintegration of the mesoporous framework and consequently the formation of phosphosilicate, similar to that reported by Matsuda et al. for the reaction between phosphoric acid and tetraethoxysilane [33].

$$
5 \mathrm{SiO}_{2}+6 \mathrm{H}_{3} \mathrm{PO}_{4} \rightarrow \mathrm{Si}_{5} \mathrm{O}\left(\mathrm{PO}_{4}\right)_{6}+9 \mathrm{H}_{2} \mathrm{O}
$$

Moreover, the Si-O-P bonds are expected to enhance the retention of phosphoric acid molecules in the phosphosilicate and thus improve the proton conductivity of the composite membrane.

The microstructure and particle size of Pt electrocatalysts before and after the stability testing were examined by TEM with the results presented in Fig. 8. The average particle size of Pt catalyst of the fresh-prepared MEAs was $3.4 \mathrm{~nm}$ (Fig. 8A). However, the size of $\mathrm{Pt}$ nanoparticles increased significantly after the long-term stability testing at $200{ }^{\circ} \mathrm{C}$. In the case of PA/PBI membrane cells, the average Pt particle size was 6.7 and $10.5 \mathrm{~nm}$ for anode and cathode after testing for $2400 \mathrm{~h}$ (Fig.8B and C), respectively, much larger than the original size of $3.4 \mathrm{~nm}$ of the $\mathrm{Pt} / \mathrm{C}$ catalysts. This is consistent with the observed significant agglomeration of Pt-based catalysts of PA/PBI membrane cells operated at a high temperature of $190{ }^{\circ} \mathrm{C}[8]$. Moreover, the increase in the agglomeration of Pt nanoparticles in the cathode is much higher than observed in the anode. This may be due to a higher water vapour pressure produced in the cathode layer as compared to the anode layer of the pristine PA/PBI membrane based fuel cells during operation [34]. In the case of the PA/PBI/PWA-meso-silica composite membrane fuel cell, the average particle size of the Pt catalyst was 4.0 and $5.7 \mathrm{~nm}$ in the anode and cathode layers after testing for $2700 \mathrm{~h}$ (Fig.8D and E), respectively, significantly smaller than those in the pristine PA/PBI membrane fuel cell. These results demonstrate that the addition of the PWA-meso-silica filler in PBI also increases the stability of the Pt catalyst in the electrodes, 
particularly in the cathode layer. However, EDS analysis indicates the presence of $\mathrm{C}, \mathrm{O}, \mathrm{Pt}$ and $\mathrm{P}$ but not $\mathrm{W}$ in the cathode of both PA/PBI and PA/PBI/PWA-meso-silica membrane fuel cells (see Fig.9) after long-term stability testing. This suggests that the PWA-meso-silica inorganic additive remains within the PBI matrix.

\subsection{Role of PWA-meso-silica in the composite membrane}

The interaction between phosphoric acid and silicate was studied in order to fundamentally understand the role of PWA-meso-silicate in the PA/PBI/PAW-meso-silicate composite membranes. Fig.10 presents XRD phase, proton conductivity and stability data of pure phosphosilicate, in situ formed phosphosilicate in PA (phosphisilicate/PA) and a simple mixture of pure PA and phosphosilicate (phosphisilicate+PA), all measured at $250{ }^{\circ} \mathrm{C}$ under anhydrous conditions, noting that the phosphosilicate phase, $\mathrm{Si}_{5} \mathrm{O}\left(\mathrm{PO}_{4}\right)_{6}$ can be prepared by condensation of $\mathrm{Si}-\mathrm{OH}$ and $\mathrm{P}-\mathrm{OH}$ on heating of a $\mathrm{SiO}_{2}-\mathrm{H}_{3} \mathrm{PO}_{4}$ mixture at about $200{ }^{\circ} \mathrm{C}[35]$. The purpose of this stability test at $250{ }^{\circ} \mathrm{C}$ was to accelerate the degradation process of these samples.

The results shows that the proton conductivity of the pure phosphosilciate phase is low, 3.6 $\times 10^{-3} \mathrm{~S} \mathrm{~cm}^{-1}$ at $250{ }^{\circ} \mathrm{C}$, but is stable (Fig.10B), which is in agreement with data reported elsewhere[33]. When pure phosphosilicate was mixed with phosphoric acid, the proton conductivity of the mixture increases to $3.7 \times 10^{-2} \mathrm{~S} \mathrm{~cm}^{-1}$ at $250{ }^{\circ} \mathrm{C}$. However, the stability in proton conductivity of the mixture is very poor with a decrease to $1.7 \times 10^{-3} \mathrm{~S} \mathrm{~cm}^{-1}$ after testing for $72 \mathrm{~h}$, an order of magnitude lower than the initial conductivity. This is probably due to the condensation and separation of PA from the phosphosilicate phase at elevated high temperatures. The condensation of short-chain phosphate would be irreversible in a dry atmosphere condition, resulting in a diminution in proton conductivity[36]. On the other hand, the in situ formed phosphosilicates or phosphosilicate/PA showed a high proton conductivity of $7.2 \times 10^{-2} \mathrm{~S} \mathrm{~cm}^{-1}$ at $250{ }^{\circ} \mathrm{C}$, more than an order of magnitude higher than $3.6 \times 10^{-3} \mathrm{~S} \mathrm{~cm}^{-1}$ 
with the pure phosphosilicate phase. Most importantly, the proton conductivity of the phosphosilicate/PA phase is very stable during testing for $120 \mathrm{~h}$ at $250{ }^{\circ} \mathrm{C}$ (Fig.10B). Matsuda et al studied the conductivity of phosphosilicate gels with different P/Si ratio and reported a stable proton conductivity of $1 \times 10^{-2} \mathrm{~S} \mathrm{~cm}^{-1}$ at $150{ }^{\circ} \mathrm{C}$ and $0.4 \% \mathrm{RH}$ for the gel with a $\mathrm{P} / \mathrm{Si}$ mole ratio of 1.0 to 1.5[37]. XRD and MAS-NMR studies showed that phosphosilicate gels can hold large amount of phosphorus and the Si-O-P-OH groups in the phosphosilicate gels enhance the retention of the adsorbed water, thus resulting in high conductivity at high temperature and low $\mathrm{RH}[37]$. The much higher proton conductivity of the in situ formed phosphosilicate phase, as compared to the pure phosphosilicate phase, is an indicative of the retention of a large amount of PA in the in situ formed phosphosilicate phase, similar to the phosphosilicate gels[37, 38]. On the other hand, the excellent stability of the in situ formed phosphosilicate phase, as compared to the mixed PA and phosphosilicate phase (i.e., phosphosilicate+PA), implies the presence of $\mathrm{PA} /$ phosphosilicate nanoclusters (NCs), formed during the in situ formation of the phosphosilicate phase. The PA/phosphosilicate NCs are capable of holding significant amount of PA, which is responsible for the excellent proton conductivity and stability, as demonstrated in this study.

TEM and SAXS analysis showed the disintegration of the mesoporous structure of the impregnated PWA-meso-silicate along with the detection of phosphosilicate phase within the PBI matrix (Fig.5), indicating the in operanto or in situ formation of phosphosilicate between meso-silica and PA within the PBI matrix during the stability testing at $200{ }^{\circ} \mathrm{C}$. The exceptional performance, stability in proton conductivity, and low ohmic resistance of the PA/PBI/PWAmeso-silica membrane fuel cell measured at $200{ }^{\circ} \mathrm{C}$ at a constant current load of $200 \mathrm{~mA} \mathrm{~cm}{ }^{-2}$ (Figs.4-6) implied that the formation of an in situ phosphosilicate phase within the PBI membrane is also capable of holding a large amount of PA, forming PA/phosphosilicate NCs, similar to those discussed above. As PA/phosphosilicate NCs are formed in operanto in the 
PBI polymer matrix during the fuel cell operation, the connectivity at the interface between the nanocluster and PBI polymer matrix phase would be excellent. This appears to be supported by the smooth surface and no cracking of the composite membranes after testing at $200{ }^{\circ} \mathrm{C}$ for 2700 h (Fig.7A). The PA/phosphosilicate NCs can hold a significant amount of PA molecules, thereby stabilizing PA and preventing acid leaching. This explains the high stability of the proton conductivity of $\mathrm{PA} / \mathrm{PBI} / \mathrm{PWA}-m e s o$-silica composite membranes as compared to pristine PA/PBI membranes. On the other hand, PWA may play a role in the proton conductivity of the composite membranes and compensate the conductivity loss of the composite membrane due to the low PA uptake[39]. A failure to detect the tungsten in the composite may be due to the trace amount of PWA after the disintegration of the mesoporous silica structure. In conclusion, the results indicate that the fundamental reason for the high thermal stability, high proton conductivity and excellent stability of PA/PBI/PWA-meso-silica composite membrane fuel cells at $200{ }^{\circ} \mathrm{C}$ is the in situ formation of PA/phosphosilicate NCs, as illustrated schematically in Fig.11. However, more work is needed to fundamentally understand the role of PWA in the proton conductivity and stability of PA/PBI/PWA-mesosilica composite membrane fuel cells at high temperatures.

The dominant factor for the fast degradation of pristine PA/PBI membrane cells is the accelerated leaching rate of PA at high temperatures[16, 19]. In addition to agglomeration of the Pt catalyst associated with the dissolution and re-deposition of Pt particles induced by high temperatures and current loadings[40, 41] and carbon corrosion[42], acid in the electrode catalyst layer also induce grain growth and agglomeration of Pt catalysts in the case of the PA/PBI based membrane cell. This is supported by the observed significant agglomeration of Pt nanoparticles particualry in the cathode layer (Fig.8 and Table 2), which is partially responsible for the performance degradation of the PA/PBI membrane fuel cell at high temperature[43]. Liu et al. revealed that extra PA in the electrodes resulted in the drastic 
degradation in performance and reduced stability of PA/PBI membrane fuel cells [44]. The formation of $\mathrm{PA} /$ phosphosilicate NCs stabilizes the acid at high temperature, diminishing the detrimental influence of acid on the agglomeration of Pt nanoparticles of PA/PBI/PWA-mesosilica composite membrane fuel cells. This is exactly the case as indicated by the significantly reduced grain growth of $\mathrm{Pt}$ particles in the case of the PA/PBI/PWA-meso-silica composite membrane cell (see Fig.8).

\section{Conclusions}

The microstructure, the PA uptake, swelling ratio, mechanical and conductivity properties of PA/PBI/ PWA-meso-silica membranes depends strongly on the loading of PWA-meso-silica. The results indicate that the optimum limit of PWA-meso-silica loading in the PA/PBI membranes is $15 \mathrm{wt} \%$. PA doped PBI membrane with $15 \mathrm{wt} \%$ PWA-meso-silica showed good microstructure, reduced PA uptake and swelling ratio, good mechanical properties, exceptional performance durability, stable proton conductivity and open circuit voltage under a constant current load of $200 \mathrm{~mA} \mathrm{~cm}^{-2}$ at $200{ }^{\circ} \mathrm{C}$ for $2,700 \mathrm{~h}$. The results also showed that pristine PA/PBI membrane cells cannot be operated at $200{ }^{\circ} \mathrm{C}$ and fail catastrophically after operation for $\sim 1450$ $\mathrm{h}$ under identical test conditions. Detailed microstructural and phase analysis data indicated the disintegration of the mesoporous silica structure of the impregnated PWA-meso-silica and reaction between meso-silica and PA phases under the conditions of this study. The formation of phosphosilicate phases were clearly identified within the PBI polymer matrix for the $\mathrm{PA} / \mathrm{PBI} / \mathrm{PWA}-m e s o$-silica composite membrane cell during the polarization at $200 \mathrm{~mA} \mathrm{~cm}{ }^{-2}$ and $200{ }^{\circ} \mathrm{C}$. Additional investigation of pure, in situ formed and mixed PA and phosphosilicate evidently demonstrated that in situ formed phosphosilicates can form PA/phosphosilicate NCs in the PBI matrix, which substantially stabilizes by immobilizing phosphoric acid in cluster structures and inhibits acid leaching from the PA/PBI/PWA-meso-silica composite membrane 
during fuel cell operation at $200{ }^{\circ} \mathrm{C}$. The highly stable PA/phosphosilicate NCs maintained a high proton conductivity of composite membranes, also effectively alleviating the detrimental influence of excess acid in the aggregation of the Pt nanoparticles in both the anode and cathode layers of the membrane fuel cell.

\section{Acknowledgement}

This work was financially supported by the Australian Research Council under the Discovery Project Scheme (project number: DP150102025 and DP150102044). The authors would like to thank the staff and facilities of the Centre of Microscopy and Microanalysis at the University of Queensland, and the facilities and technical assistance of the National Imaging Facility at the Centre for Microscopy, Characterization \& Analysis, the University of Western Australia, a facility funded by the University, State, and Commonwealth Government. The synchrotron SAXS was conducted at Australian Synchrotron, Melbourne, Australia. Innovation Fund Denmark is also acknowledged for financial support of the 4M Centre (0603-00527B).

\section{References:}

[1] A. Chandan, M. Hattenberger, A. El-Kharouf, S.F. Du, A. Dhir, V. Self, B.G. Pollet, A. Ingram, W. Bujalski, J. Power Sources, 231 (2013) 264-278.

[2] S.P. Jiang, Journal of Materials Chemistry A, 2 (2014) 7637-7655.

[3] Q.F. Li, J.O. Jensen, R.F. Savinell, N.J. Bjerrum, Prog. Polym. Sci., 34 (2009) 449-477.

[4] Q. Li, R. He, J.O. Jensen, N.J. Bjerrum, Chem. Mater., 15 (2003) 4896-4915.

[5] J.-P. Melchior, G. Majer, K.-D. Kreuer, Phys. Chem. Chem. Phys., 19 (2017) 601-612.

[6] J.S. Wainright, J.T. Wang, D. Weng, R.F. Savinell, M. Litt, J. Electrochem. Soc., 142 (1995) L121-L123.

[7] T.J. Schmidt, J. Baurmeister, J. Power Sources, 176 (2008) 428-434.

[8] Y. Oono, T. Fukuda, A. Sounai, M. Hori, J. Power Sources, 195 (2010) 1007-1014.

[9] Y. Oono, A. Sounai, M. Hori, J. Power Sources, 210 (2012) 366-373.

[10] Y. Oono, A. Sounai, M. Hori, J. Power Sources, 241 (2013) 87-93.

[11] T.J. Schmidt, J. Baurmeister, ECS Transactions, 3 (2006) 861-869.

[12] T. Søndergaard, L.N. Cleemann, H. Becker, D. Aili, T. Steenberg, H.A. Hjuler, L. Seerup, Q. Li, J.O. Jensen, J. Power Sources, 342 (2017) 570-578.

[13] Q. Li, R. He, J.-A. Gao, J.O. Jensen, N.J. Bjerrum, J. Electrochem. Soc., 150 (2003) A1599-A1605.

[14] Q. Li, R. He, J.O. Jensen, N.J. Bjerrum, Fuel Cells, 4 (2004) 147-159.

[15] S. Galbiati, A. Baricci, A. Casalegno, R. Marchesi, Int. J. Hydrogen Energy, 38 (2013) 6469-6480.

[16] S. Yu, L. Xiao, B.C. Benicewicz, Fuel Cells, 8 (2008) 165-174. 
[17] C. Zhang, W. Zhou, M.M. Ehteshami, Y. Wang, S.H. Chan, Energy Convers. Manage., 105 (2015) 433-441.

[18] Q. Li, J.O. Jensen, R.F. Savinell, N.J. Bjerrum, Prog. Polym. Sci., 34 (2009) 449-477.

[19] S.H. Eberhardt, T. Lochner, F.N. Büchi, T.J. Schmidt, J. Electrochem. Soc., 162 (2015) F1367-F1372.

[20] A. Shabanikia, M. Javanbakht, H.S. Amoli, K. Hooshyari, M. Enhessari, Electrochim. Acta, 154 (2015) 370-378.

[21] G. Nawn, G. Pace, S. Lavina, K. Vezzu, E. Negro, F. Bertasi, S. Polizzi, V. Di Noto, ChemSusChem, 8 (2015) 1381-1393.

[22] S. Wang, C.J. Zhao, W.J. Ma, N. Zhang, Y.R. Zhang, G. Zhang, Z.G. Liu, H. Na, J. Mater. Chem. A, 1 (2013) 621-629.

[23] G. Nawn, G. Pace, S. Lavina, K. Vezzu, E. Negro, F. Bertasi, S. Polizzi, V. Di Noto, Macromolecules, 48 (2015) 15-27.

[24] A. Eguizabal, J. Lemus, M.P. Pina, J. Power Sources, 222 (2013) 483-492.

[25] D. Aili, J. Zhang, M.T.D. Jakobsen, H.J. Zhu, T.Y. Yang, J. Liu, M. Forsyth, C. Pan, J.O. Jensen, L.N. Cleemann, S.P. Jiang, Q.F. Li, Journal of Materials Chemistry A, 4 (2016) 4019-4024.

[26] A.D. Modestov, M.R. Tarasevich, V.Y. Filimonov, N.M. Zagudaeva, Electrochim. Acta, 54 (2009) 7121-7127.

[27] J. Zeng, P.K. Shen, S.F. Lu, Y. Xiang, L. Li, R. De Marco, S.P. Jiang, J. Membr. Sci., 397 (2012) 92-101. [28] J.O. Jensen, Q. Li, R. He, C. Pan, N.J. Bjerrum, J. Alloy. Compd., 404 (2005) 653-656.

[29] R.H. He, Q.F. Li, G. Xiao, N.J. Bjerrum, J. Membr. Sci., 226 (2003) 169-184.

[30] Y.C. Jin, M. Nishida, W. Kanematsu, T. Hibino, J. Power Sources, 196 (2011) 6042-6047.

[31] A. Shabanikia, M. Javanbakht, H.S. Amoli, K. Hooshyari, M. Enhessari, J. Electrochem. Soc., 161 (2014) F1403-F1408.

[32] K. Tadanaga, Y. Michiwaki, T. Tezuka, A. Hayashi, M. Tatsumisago, J. Membr. Sci., 324 (2008) 188191.

[33] A. Matsuda, T. Kanzaki, K. Tadanaga, M. Tatsumisago, T. Minami, Solid State lonics, 154-155 (2002) 687-692.

[34] J. Hu, H. Zhang, Y. Zhai, G. Liu, J. Hu, B. Yi, Electrochim. Acta, 52 (2006) 394-401.

[35] S.P. Szu, L.C. Klein, M. Greenblatt, J. Non-cryst. Solid, 143 (1992) 21-30.

[36] T. Matsui, S. Takeshita, Y. Iriyama, T. Abe, Z. Ogumi, J. Electrochem. Soc., 152 (2005) A167-A170.

[37] A. Matsuda, T. Kanzaki, K. Tadanaga, M. Tatsumisago, T. Minami, Electrochim. Acta, 47 (2001) 939-944.

[38] A. Matsuda, T. Kanzaki, M. Tatsumisago, T. Minami, Solid State lonics, 145 (2001) 161-166.

[39] X. Xu, S. Tao, P. Wormald, J.T.S. Irvine, J. Mater. Chem., 20 (2010) 7827-7833.

[40] G. Liu, H. Zhang, J. Hu, Y. Zhai, D. Xu, Z.-g. Shao, J. Power Sources, 162 (2006) 547-552.

[41] J.A. Bett, K. Kinoshita, P. Stonehart, J. Catal., 35 (1974) 307-316.

[42] L.N. Cleemann, F. Buazar, Q. Li, J.O. Jensen, C. Pan, T. Steenberg, S. Dai, N.J. Bjerrum, Fuel Cells, 13 (2013) 822-831.

[43] J. Hu, H. Zhang, Y. Zhai, G. Liu, B. Yi, Int. J. Hydrogen Energy, 31 (2006) 1855-1862.

[44] S. Matar, A. Higier, H. Liu, J. Power Sources, 195 (2010) 181-184. 


\section{Figure captions:}

1. Scanning electron micrographs of cross-section and surface of PBI/PWA-meso-silica membranes with PWA-meso-silica loadings of (A,B) $0 \mathrm{wt} \%$, (C) $5 \mathrm{wt} \%$, (D) $10 \mathrm{wt} \%$, (E,F) $15 \mathrm{wt} \%$, (G) $20 \mathrm{wt} \%$ and $(\mathrm{H}) 40 \mathrm{wt} \%$. Inset in $(\mathrm{F})$ is an enlarged image of the light region of the surface of PBI/PBI-meso-silica with a loading of $15 \mathrm{wt} \% \mathrm{PWA}$-mesosilica.

2. (A) TEM image of the PBI/PWA-meso-silica composite membrane. (B) Enlarged TEM image and $(\mathrm{C})$ the EDS spectrum of the rectangular area in (A). PWA-meso-silica loading in the composite membrane was $15 \mathrm{wt} \%$.

3. Stress-strain curves and corresponding elastic modulus for the PBI/PWA-meso-silica composite membranes with PWA-meso-SiO 2 loadings of $0-40 \mathrm{wt} \%$ before $(\mathrm{A}, \mathrm{B})$ and after $(C, D)$ phosphoric acid doping. The heights of the gray bars in $(B, D)$ represent the average values and the standard deviations are indicated by the error bars.

4. (A) Long-term stability testing of pristine PA/PBI membrane and PA/PBI/PWA-mesosilica composite membrane cells; (B) plots of the in situ membrane conductivity and (C) open circuit voltage. The fuel cells were tested at a constant current density of 200 $\mathrm{mA} \mathrm{cm} \mathrm{cm}^{-2}$ and $200{ }^{\circ} \mathrm{C}$ in $\mathrm{H}_{2}$ /air under anhydrous conditions. PWA-meso-silica loading in the composite membrane was $15 \mathrm{wt} \%$.

5. Polarization curves of $\mathrm{PA} / \mathrm{PBI}$ and $\mathrm{PA} / \mathrm{PBI} / \mathrm{PWA}-m e s o$-silica membrane fuel cells at $200{ }^{\circ} \mathrm{C}$ after polarization at a constant current density of $200 \mathrm{~mA} \mathrm{~cm}^{-2}$ for (A) $0 \mathrm{~h}$; (B) $1750 \mathrm{~h}$; and (C) $2400 \mathrm{~h}$. PWA-meso-silica loading in the composite membrane was 15 wt $\%$.

6. (A) EIS Nyquist plots and (B) membrane resistance and electrode polarization resistance of the PA/PBI membrane and PA/PBI/PWA-meso-silica membrane fuel cells as a function of polarization time at $200 \mathrm{~mA} \mathrm{~cm}^{-2}$ and $200{ }^{\circ} \mathrm{C}_{\text {in }} \mathrm{H}_{2}$ /air under anhydrous conditions. PWA-meso-silica loading in the composite membrane was $15 \mathrm{wt} \%$.

7. (A, B) SEM images of the surface of a PA/PBI/PWA-meso-silica composite membrane after $2700 \mathrm{~h}$ of fuel cell testing, (C) SAXS profiles of the PA/PBI/PWA-meso-silica composite membrane before and after stability testing, and (D) XRD profiles of pristine PBI, PA/PBI and PA/PBI/PWA-meso-silica composite membranes after fuel cell stability testing. PWA-meso-silica loading in the composite membrane was $15 \mathrm{wt} \%$.

8. TEM images and related size distribution of (A) original $\mathrm{Pt} / \mathrm{C}$ catalyst before testing, (B) $\mathrm{Pt} / \mathrm{C}$ anode and (C) $\mathrm{Pt} / \mathrm{C}$ cathode of PA/PBI membrane fuel cells, and (D) $\mathrm{Pt} / \mathrm{C}$ anode and (E) $\mathrm{Pt} / \mathrm{C}$ cathode of PA/PBI/PWA-meso-silica composite membrane fuel cells. The cells were tested at $200{ }^{\circ} \mathrm{C}$ with a current load of $200 \mathrm{~mA} \mathrm{~cm}^{-2}$ for $2400 \mathrm{~h}$ with the PA/PBI membrane fuel cell and $2700 \mathrm{~h}$ with the PA/PBI/PWA-meso-silica membrane fuel cell. PWA-meso-silica loading in the composite membrane was $15 \mathrm{wt} \%$.

9. EDS of the catalyst layer in cathodes of (A) PA/PBI membrane fuel cell and (B) PA/PBI/PWA-meso-silica membrane fuel cell after the long-term stability test at 200 ${ }^{\circ} \mathrm{C}$. Inset is the SEM image of the catalyst layer. PWA-meso-silica loading in the composite membrane was $15 \mathrm{wt} \%$.

10. (A) XRD and (B) proton conductivity data for phosphosilicate, a mixture of phosphosilicate and phosphoric acid (phosphosilicate + PA) and in situ synthesized phosphosilicate/PA samples measured at $250{ }^{\circ} \mathrm{C}$ under anhydrous conditions.

11. Scheme for the formation of PA/phophosilicate cluster structures and its role in the stabilization of PA and the proton conduction of PA/PBI/PWA-meso-silica composite membranes at elevated high temperature of $200{ }^{\circ} \mathrm{C}$. 
Table 1. Physical properties of PBI and PBI/PWA-meso-silica composite membrane including elastic modulus, phosphoric acid uptake and volume swelling after phosphoric acid doping.

\begin{tabular}{|c|c|c|c|c|c|c|}
\hline \multirow{2}{*}{$\begin{array}{l}\text { PBI/PWA- } \\
\text { meso-silica } \\
\text { Membrane } \\
\text { wt\% filler }\end{array}$} & \multicolumn{2}{|c|}{ Elongation, \% } & \multicolumn{2}{|c|}{ Elastic modulus, $\mathrm{MPa}$} & \multirow{2}{*}{$\begin{array}{c}\text { PA uptake, } \\
\text { wt } \%\end{array}$} & \multirow{2}{*}{$\begin{array}{c}\text { Volume } \\
\text { swelling, } \\
\text { vol\% }\end{array}$} \\
\hline & $\begin{array}{c}\text { Before PA } \\
\text { doping }\end{array}$ & $\begin{array}{c}\text { After PA } \\
\text { doping }\end{array}$ & $\begin{array}{c}\text { Before PA } \\
\text { doping }\end{array}$ & $\begin{array}{c}\text { After PA } \\
\text { doping }\end{array}$ & & \\
\hline $0 \%$ & $10.4 \pm 4.7$ & $58.3 \pm 22.1$ & $3384 \pm 409$ & $52.3 \pm 0.6$ & 341 & 242 \\
\hline $5 \%$ & $11.0 \pm 3.4$ & $114.5 \pm 21.0$ & $2755 \pm 367$ & $54.3 \pm 8.8$ & 308 & 167 \\
\hline $10 \%$ & $3.2 \pm 0.8$ & $108.8 \pm 11.3$ & $1873 \pm 323$ & $41.8 \pm 4.4$ & 284 & 163 \\
\hline $15 \%$ & $4.4 \pm 0.6$ & $88.3 \pm 39.5$ & $1992 \pm 282$ & $33.0 \pm 12.3$ & 242 & 137 \\
\hline $20 \%$ & $2.3 \pm 0.2$ & $122.7 \pm 13.6$ & $2350 \pm 398$ & $53.3 \pm 4.4$ & 226 & 128 \\
\hline $30 \%$ & $2.7 \pm 1.2$ & $126.9 \pm 29.2$ & $1878 \pm 654$ & $32.9 \pm 11.8$ & 219 & 130 \\
\hline $40 \%$ & $1.4 \pm 0.2$ & $91.5 \pm 16.5$ & $1589 \pm 409$ & $25.0 \pm 7.5$ & 215 & 100 \\
\hline
\end{tabular}

Table 2. Peak power density, membrane and electrode resistance and Pt particle size of anode and cathode of PA/PBI and PA/PBI/PWA-meso-silica composite membrane fuel cells before and after stability test at $200 \mathrm{~mA} \mathrm{~cm}^{-2}$ and $200{ }^{\circ} \mathrm{C}$.

\begin{tabular}{|c|c|c|c|c|c|c|c|c|c|c|c|c|}
\hline \multirow[t]{3}{*}{ Cell } & \multicolumn{3}{|c|}{$\begin{array}{c}\text { Powder density / } \mathrm{mW} \\
\mathrm{cm}^{-2}\end{array}$} & \multicolumn{6}{|c|}{ Resistance / $\Omega \mathrm{cm}^{2}$} & \multicolumn{3}{|c|}{ Pt particle size / nm } \\
\hline & \multirow[b]{2}{*}{$0 \mathrm{~h}$} & \multirow[b]{2}{*}{$1750 \mathrm{~h}$} & \multirow[b]{2}{*}{$\begin{array}{l}2400 \\
\mathrm{~h}\end{array}$} & \multirow[b]{2}{*}{$0 \mathrm{~h}$} & \multicolumn{2}{|c|}{ Membrane } & \multicolumn{2}{|c|}{ Electrode } & \multirow[b]{2}{*}{$2700 \mathrm{~h}$} & \multirow[b]{2}{*}{$0 \mathrm{~h}$} & \multirow[t]{2}{*}{ Anode } & \multirow{2}{*}{$\begin{array}{l}\text { Cathode } \\
-2700 \mathrm{~h}\end{array}$} \\
\hline & & & & & $320 \mathrm{~h}$ & $2700 \mathrm{~h}$ & $0 \mathrm{~h}$ & $\begin{array}{l}320 \\
h\end{array}$ & & & & \\
\hline PA/PBI & 407 & 82.3 & 48.4 & 0.36 & 1.78 & - & 0.52 & 0.71 & - & 3.4 & 6.7 & 10.5 \\
\hline $\begin{array}{l}\mathrm{PA} / \mathrm{PBI} / \mathrm{P} \\
\text { WA-meso- } \\
\text { silica }\end{array}$ & 386 & 224.8 & 198 & 0.16 & 0.24 & 0.33 & 0.32 & 0.36 & 0.48 & 3.4 & 4.0 & 5.7 \\
\hline
\end{tabular}




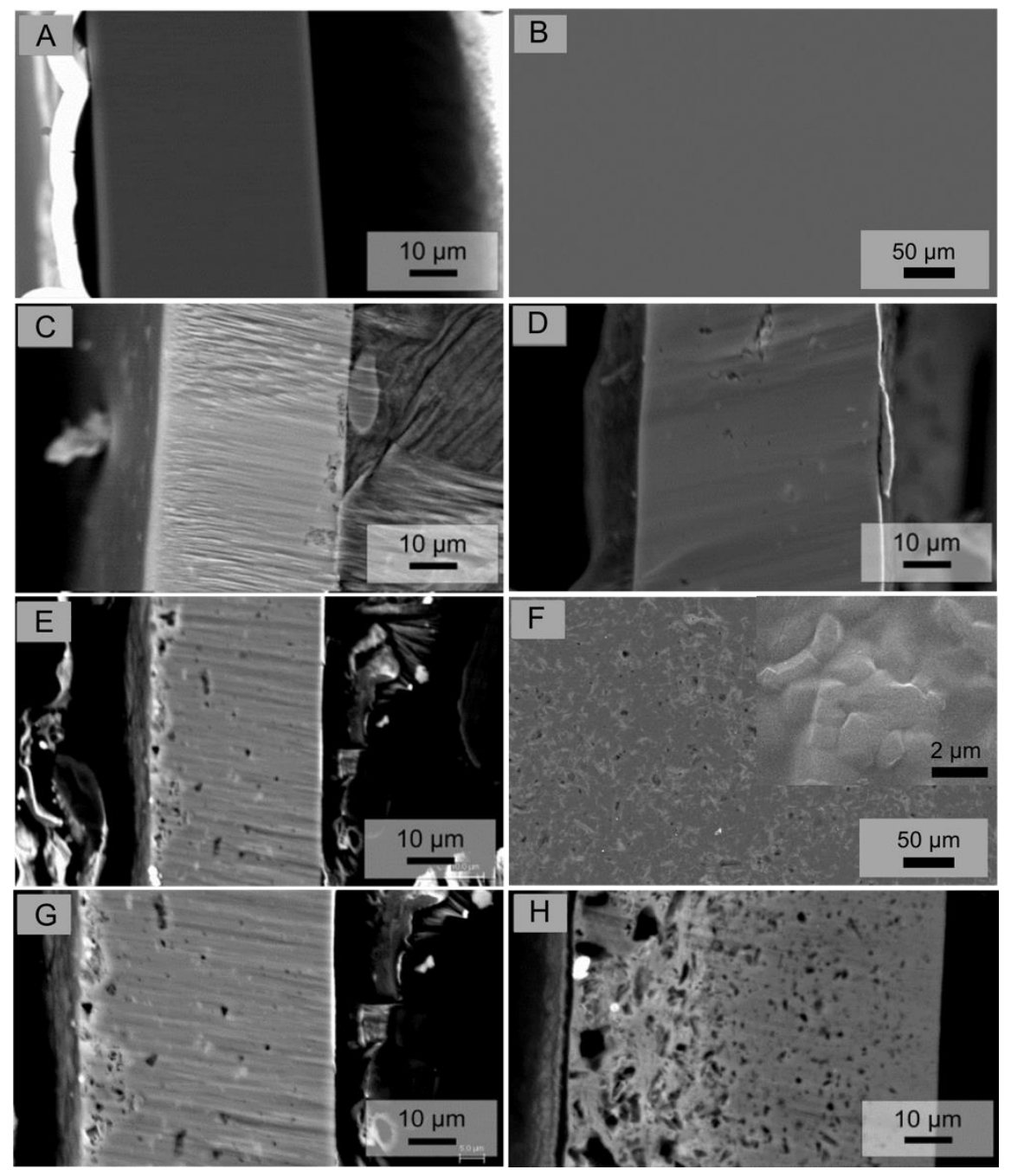

Fig. 1. 


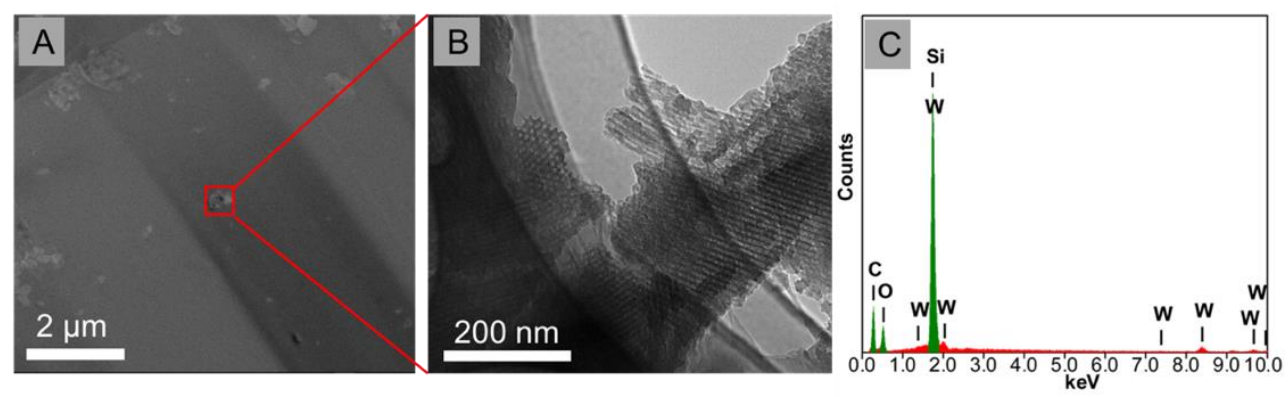

Fig. 2. 

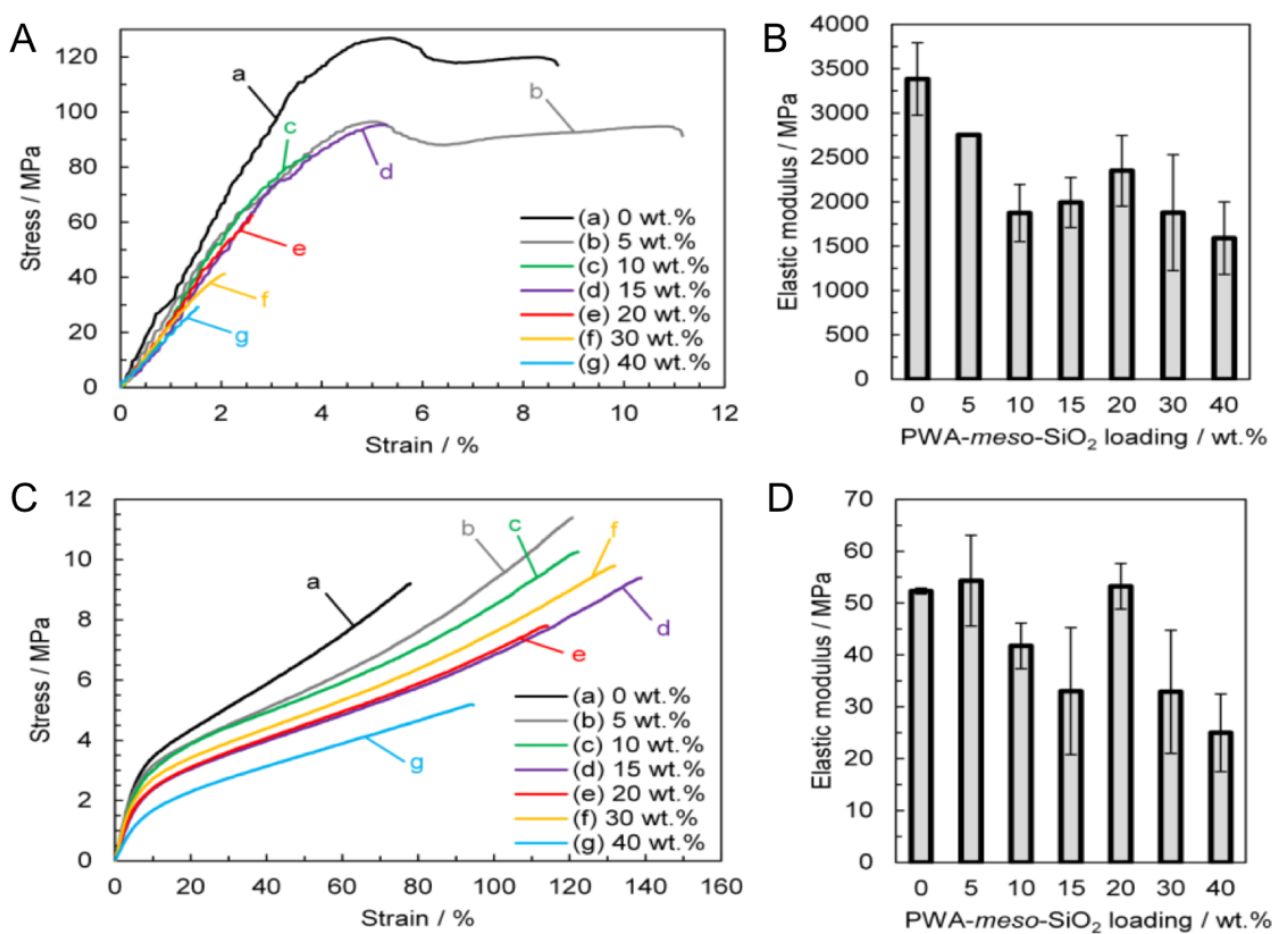

Fig. 3. 
A
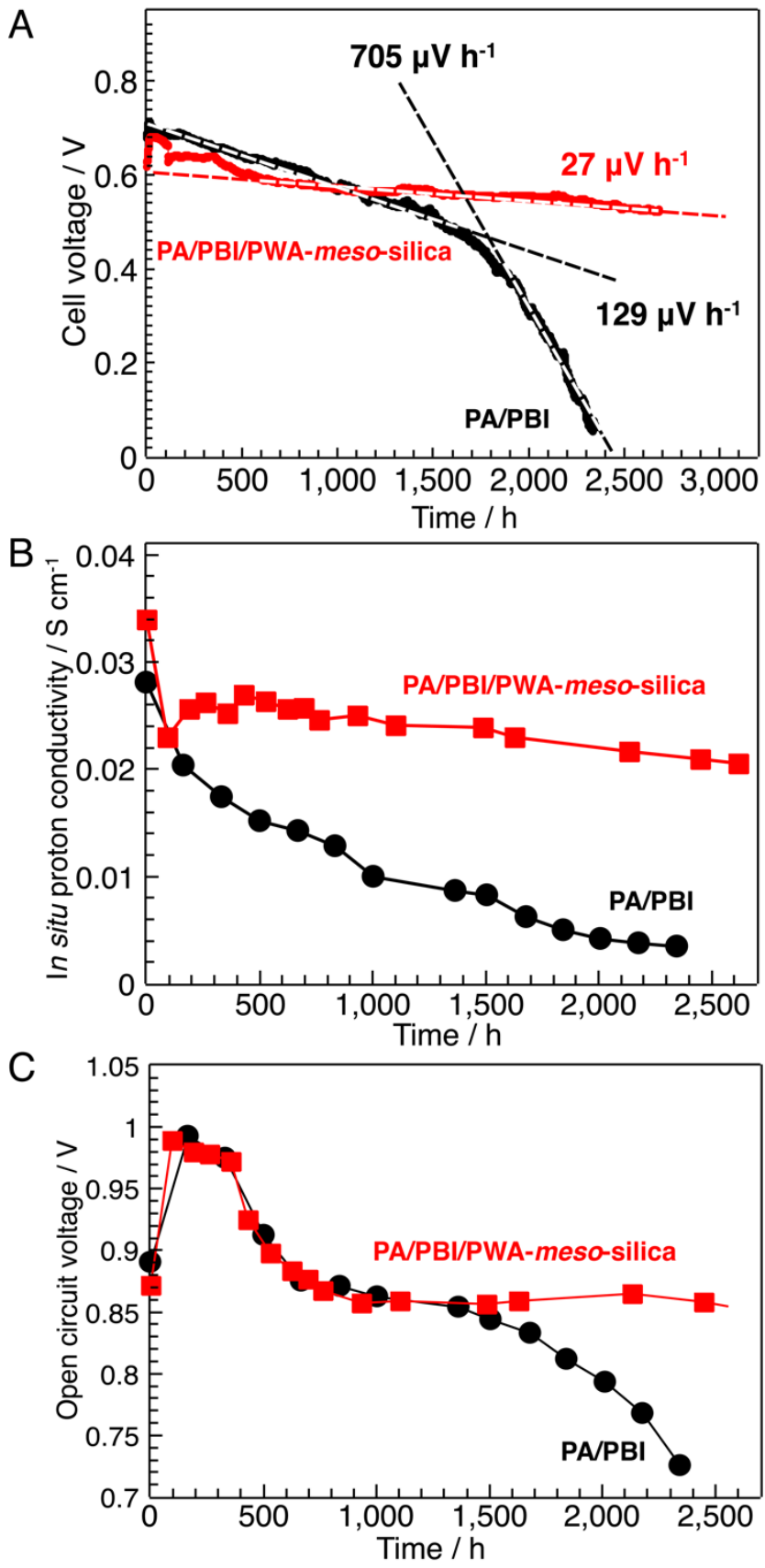

Fig. 4. 

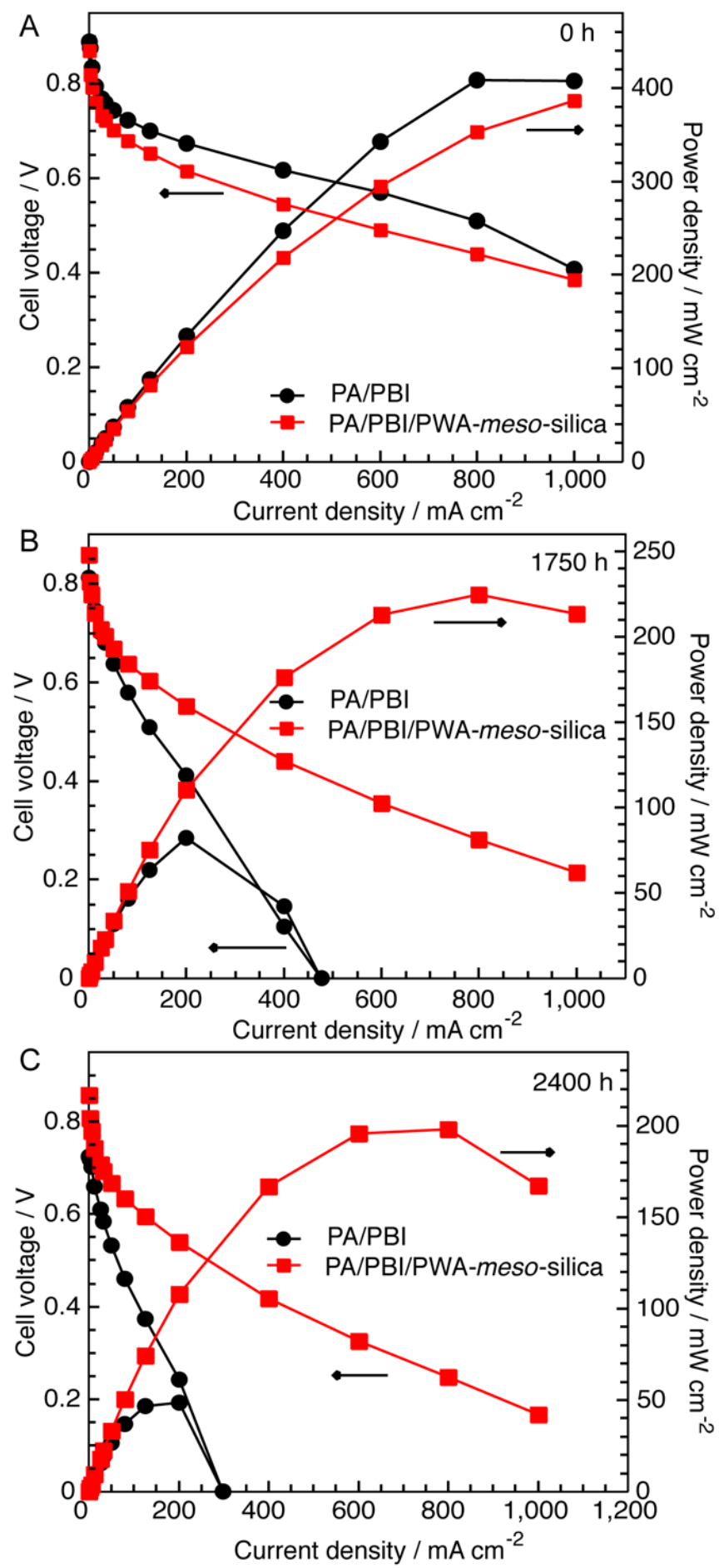

Fig. 5. 

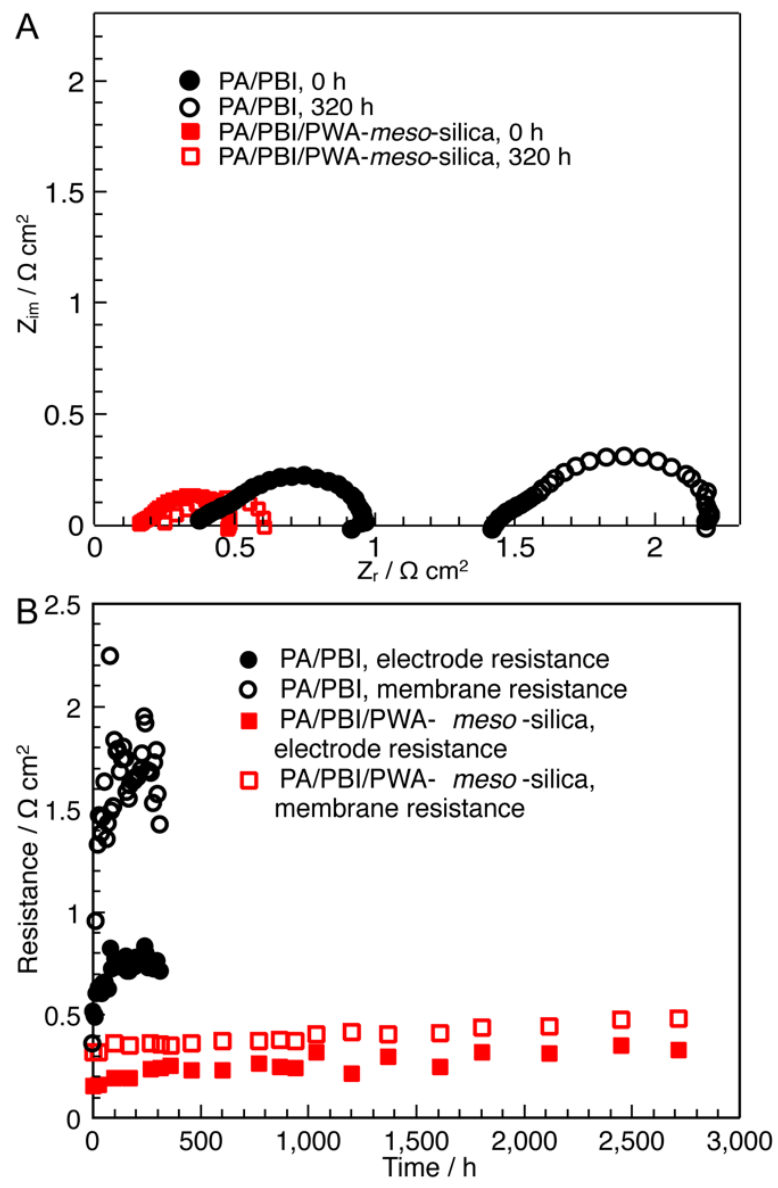

Fig. 6. 


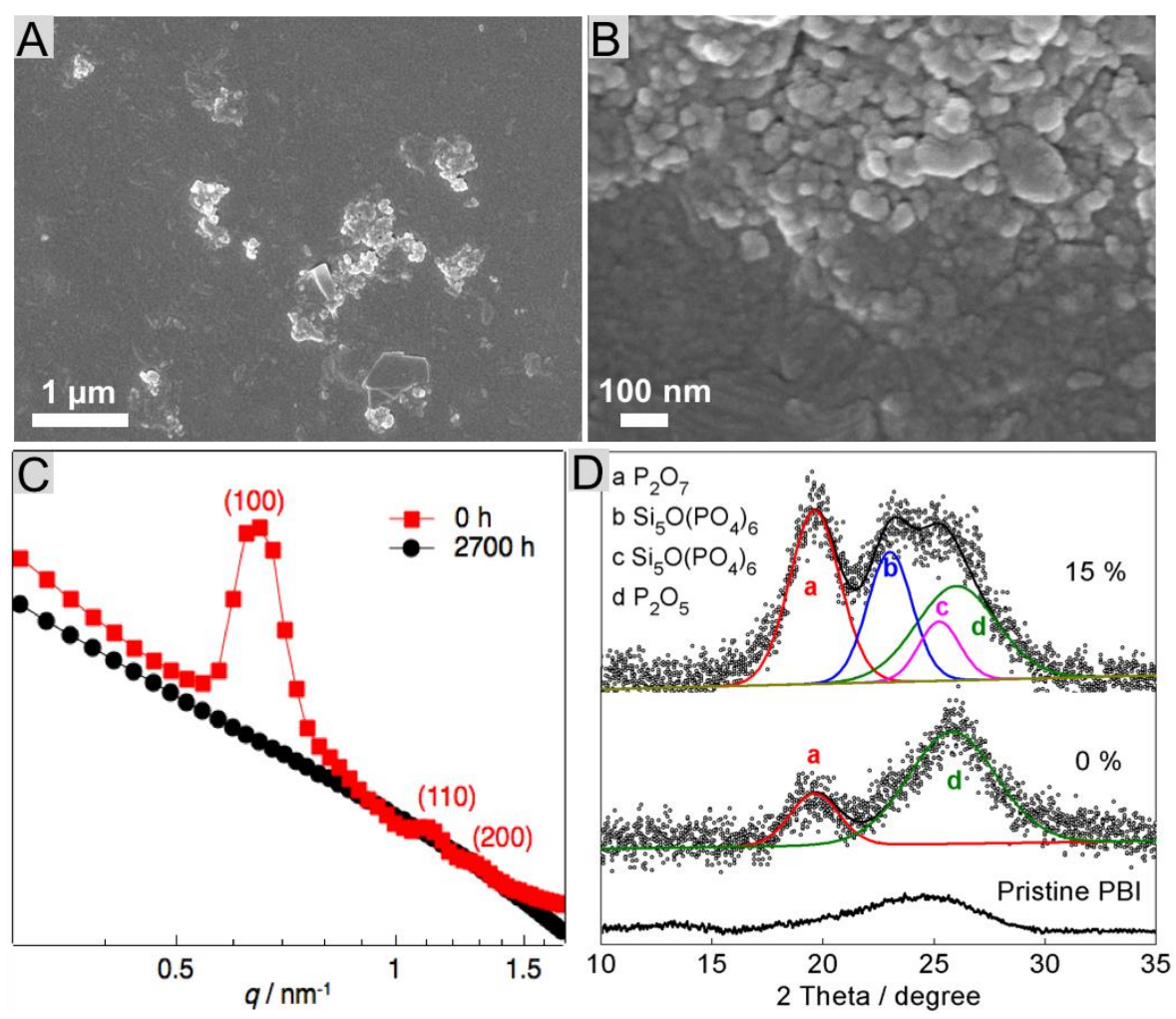

Fig. 7. 

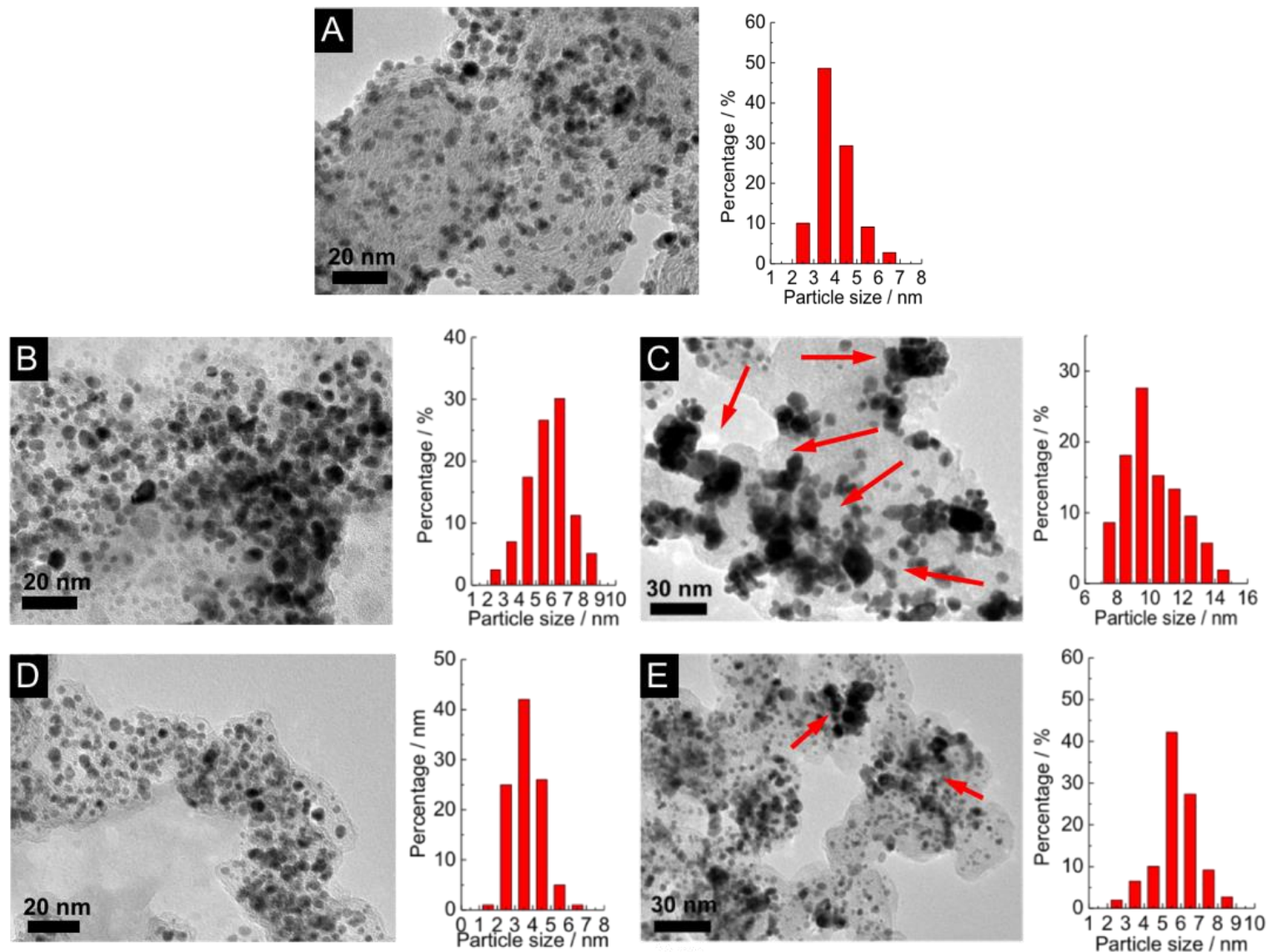

Fig. 8. 

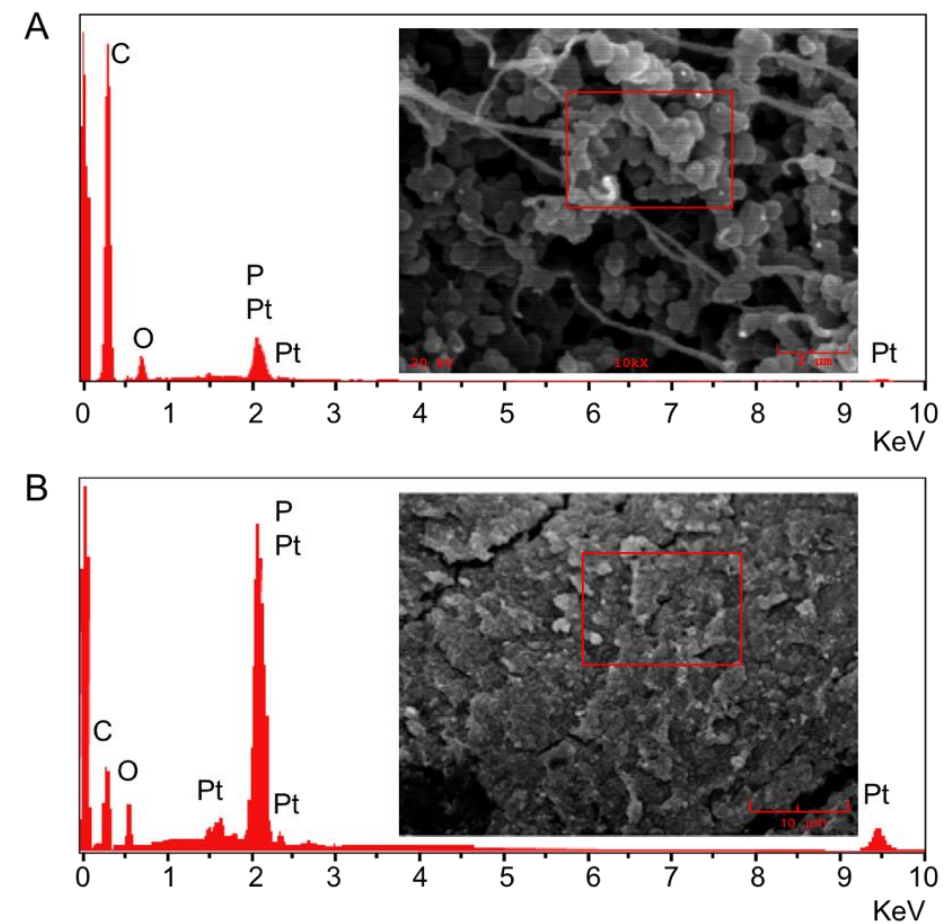

Fig. 9. 

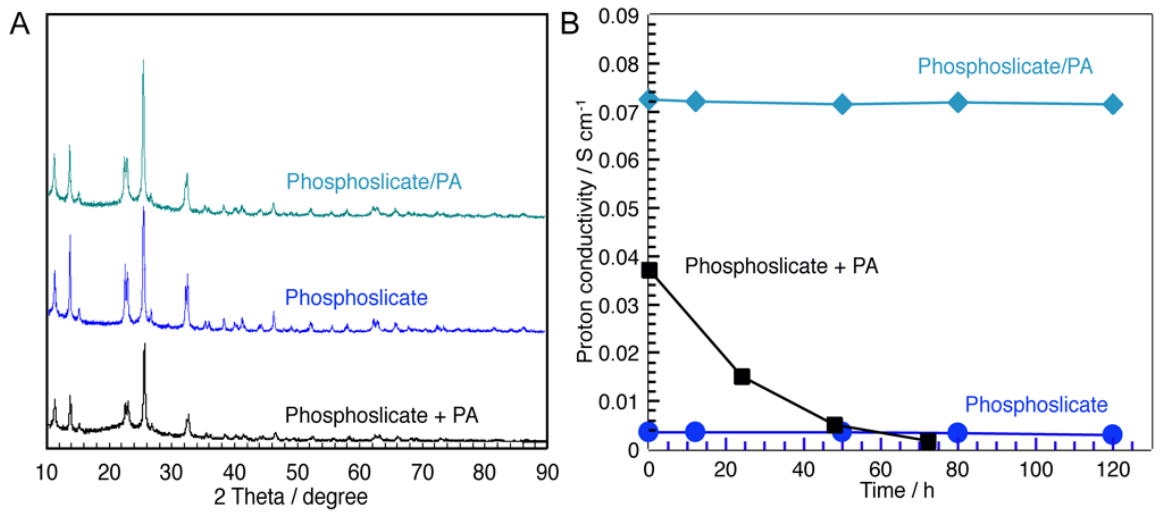

Fig. 10. 

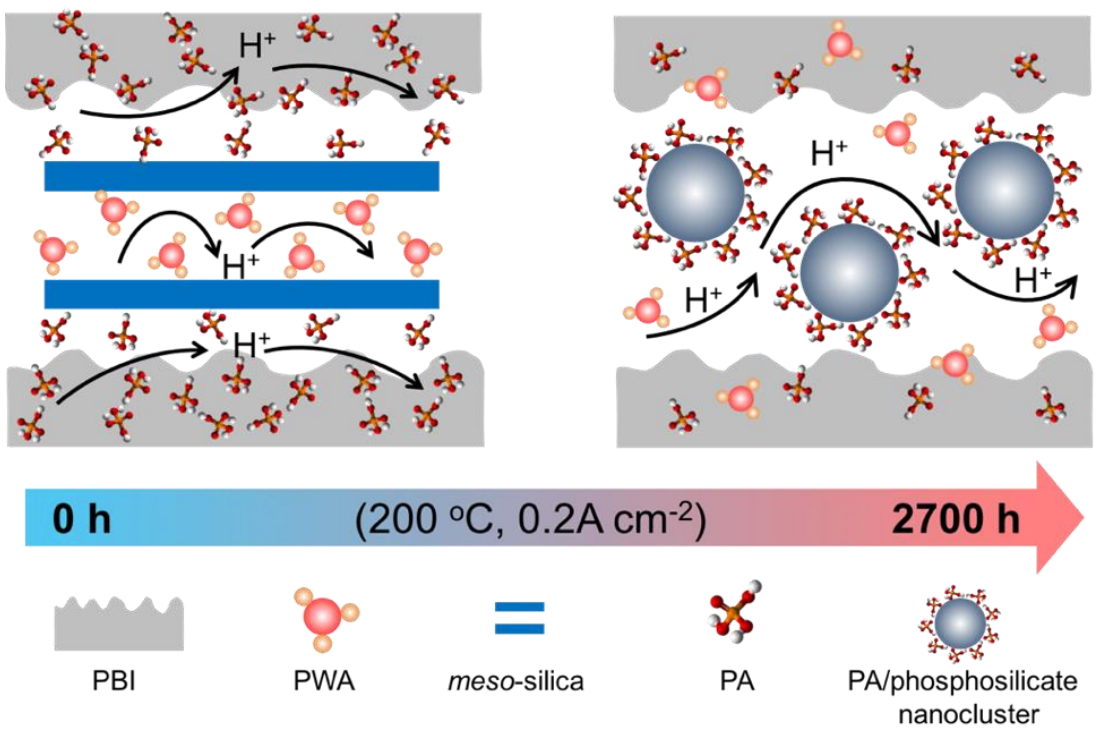

Fig. 11. 